\title{
Social Innovation in the Undergraduate Architecture Studio
}

\begin{abstract}
Aleksandra Krstikj (D)
Tecnologico de Monterrey, School of Architecture, Art and Design, López Mateos 52926, Mexico; sandra.krstik@tec.mx

Abstract: Social innovation has been gaining attention as an alternative method for defining socially constructed problems and their solutions in times of failure of more conventional methods. This study focused on the potential of undergraduate architecture students for social innovation in public space production. A novel collaborative educational method was proposed based on a conceptual framework of social extrapreneurs' platforms of exploration, experimentation and execution, and problem-based learning. The method was designed for $90 \mathrm{~h}$ synchronous and $90 \mathrm{~h}$ asynchronous work, in a remote teaching mode. The benefit of the method was foreseen in improving the social processes of public space production, especially in areas with pronounced discrimination. Social innovation in planning is crucial for the capacity of imagining better futures in the context of a system's evolutionary resilience and has the potential for democratization of public place design. Preliminary results show that the proposed method enables critical thinking, sets the base of action on social justice, and turns students into active agents of social change; thus, it provides an important contribution to the necessary, but still uncharted, paradigm shift in architectural education from an object- to people-driven design.
\end{abstract}

check for

updates

Citation: Krstikj, A. Social

Innovation in the Undergraduate

Architecture Studio. Societies 2021, 11,

26. https://doi.org/10.3390/

soc11010026

Academic Editor:

Crisanta-Alina Mazilescu

Received: 18 December 2020

Accepted: 26 February 2021

Published: 19 March 2021

Publisher's Note: MDPI stays neutral with regard to jurisdictional claims in published maps and institutional affiliations.

Copyright: (c) 2021 by the author. Licensee MDPI, Basel, Switzerland. This article is an open access article distributed under the terms and conditions of the Creative Commons Attribution (CC BY) license (https:/ / creativecommons.org/licenses/by/ $4.0 /)$.
Keywords: social innovation; architectural education; public space; place imagination; social media; inclusion

\section{Introduction}

For several decades now, researchers have studied the politics of placemaking to shed light on the way communities conceptualize and react to socio-spatial changes [1,2]. Lefebvre refers to urban public space as a social creation whose (re)production has significant implications on social and environmental systems [1]. People shape places, but places also shape people. The way we as social agents interact with a place and with other people defines that place meanings and molds relationships and identities [3].

Some developed countries have used charrette workshops to engage local communities in designing shared places or even large-scale urban plans [4-6]. While the idea of "working together" is appealing in concept, its practical implementation can be difficult. Some of the main challenges related to this type of participatory planning are found in the requirement for a high level of public awareness where input should be needed and wanted, high cost for the organization, working with community representatives instead of larger groups that can lead to more subjective common place-framing, and limited time that is often not sufficient for understanding, let alone experimenting, with advanced technological tools [7-9]. In regions where low public awareness, oppression of vulnerable groups, and underfunding are recurring issues $[10,11]$, charrettes can be difficult to implement. Thus, the challenge still lies in designing the social process of placemaking, whereby innovation will be in the way roles, tools, and structure promote inclusiveness and citizenship power $[12,13]$.

Social innovation refers to "the creation and implementation of new solutions" to social problems such as poverty, inequality, and environmental degradation [14]. When a place is collectively understood and imagined [15,16], it can bring about a connection between identity narratives and a place that can forge community strengthening and "evolutionary 
resilience". Evolutionary resilience is defined as "the ability of complex socio-ecological systems to change, adapt, and, crucially, transform", in response to stresses that might not be abrupt but rather a culmination of years-long micro-fractures produced by inequality, marginalization, and poverty, among others [17]. Thus, a community's evolutionary resilience could be understood as a long-term capacity to imagine new and better futures. For this to be achieved, it is important to go a step further-from the participation of some in the design to the inclusion of all in the design and decision-making [18].

The study presented in this article focused on architecture students' potential for social innovation in placemaking, leveraging social media as a ubiquitous tool for sharing ideas. In the new reality of social distancing and e-learning imposed by the protective measures to curb the spread of COVID-19, the time is perfect to explore the power of social media as a tool for designing more inclusive placemaking processes. The research was based on the idea that inclusive placemaking should be a collaborative and open-ended process that goes beyond participation in allowing people to define the problem, as well as the solution. The paper has four sections. The Section 1 introduces the research problem, summarizes the state-of-art, and defines the objectives of the study. The Section 2 describes a collaborative educational method to stimulate social innovation. The Section 3 presents the results of the method's application in the undergraduate architecture studio course and compares the results with a previous course where the method was not applied to assess the method's potential in delivering significant change. The Section 4 offers a short discussion on the outcomes' significance and reflects on future possible research to advance the idea of social innovation in the place production, while the Section 5 summarizes the conclusions.

\subsection{Literature Review}

In this section, the roles of research, applied knowledge, and networking in the social innovation of placemaking are reviewed. These concepts form the theoretical and didactic base of the three collaborative platforms of exploration, experimentation, and execution used in the method for this study.

The production of meaning and place are intrinsically linked and occur as simultaneous processes in the continuous struggle over the control of resources. For Pierce et al., placemaking is a highly networked and relational process that links citizens "through a common place-frame" [19]. Nevertheless, while spatial proximity between people has been studied as a catalyst for developing social ties and solidarity [20], recently the role of informal interactions in place production of segregated societies has been receiving more attention. Williams asserted that the design of leisure places is often used to assert power over a place [21]. Elwood highlighted that local-level community organizations can shift the technological, institutional, and spatial approach to placemaking to strategically advance their agendas [22]. Thus, local discriminations of social organization, especially involving the white middle class, can produce different spatial narratives of urban conditions that "reproduces normatively white middle-class place imaginaries but always also produce poverty and class politics" [23]. Martin explained how neighborhood organizations use shared place understandings of the physical environment to design discursive "place-frames" and unite the locals behind a certain agenda [24]. However, they usually obscure social differences, such as ethnicity and class, thus are often contested and bring to surface latent social conflicts. Through the study, the gap between the territorial analysis of place identity and citizens' involvement in the contentious politics of placemaking becomes evident. The study adds to Harvey's argument [25] that processes of negotiation over the terms of use of a place are crucial in the politics of placemaking and creation of engaging places, especially in areas with class-driven conflicts [26].

Low notes that researching culture through the lens of place, or as she calls it "spatializing culture", provides a tool for engagement and collaborative placemaking that bridges spatial inequalities [27]. McCann argues that the class struggle in placemaking can be "understood as a cultural politics in which meanings are defined and struggled over, where social values are naturalized, and by which 'common sense' is constructed and 
contested" [28]. Terzoglou [29] insists that the architect's job is first to research qualitative structures of a lived space or "Lebenswelt" before attempting to reconstruct or re-activate places with new discourses that can ultimately change their character and define their usability. Therefore, the first stage of any social innovation in placemaking should be based on the research of existing socio-spatial relationships and structures.

One common and established form of applied knowledge in placemaking is the charrette workshop. US Environmental Protection Agency defines charrettes as "intensive, multi-disciplinary workshop with the aim of developing a design or vision for a project" that can last from one day to several weeks. The collaboration between experts and local agents seeks to define priority issues for a community and find sustainable solutions for various stakeholders [30]. By describing the design process of the Giraffe Path (GP), a 9.66-km trail from Central Park to the Cloisters, Eckenwiler [31] (p. 566) portrays how by working together, citizens, planners, and researchers were able to "weave or re-stitch ... formerly fractured communities around and across the Harlem River and, at the same time, to support outdoor physical activity". However, in the study on parks' distribution and planning in Los Angeles, Wolch et al. [32] found that discriminated groups often do not have a voice in the workshops, due to poor social organization. Thus, the community representatives that participate in a charrette do not necessarily represent the most vulnerable groups. In some cases, the problem could be invisible to a non-local but is present in other types of signifiers, such as gestures, language, names, and activities that embody historical injustices [33]. Thus, social innovation in placemaking should be carefully designed to promote inclusion and advance justice.

In the higher education context, service learning that combines community service with problem-based learning has been gaining attention as a form of applied knowledge [34]. Studies through the years consistently reveal that student's learning, critical thinking, and personal growth are enhanced by service, which is undoubtedly important for educational innovation [35-38]. Interestingly, the study by Blakey et al. [39] that focused on the faculty fellows' engagement with service-learning found that a large majority of teachers believed that they were also learning alongside students and that implementing service-learning made them better teachers. However, research on applied knowledge methods for social innovation in placemaking is scarce. Even though the self-satisfaction of achievements and understanding of sustainable development were assessed in this study as well, the focus was on the evaluation of the potential of the educational method to improve social innovation processes through collaborative platforms.

The use of networking in problem-based learning has been gaining attention in the last few decades. Reeves [40] pointed out that for successful design research, e-learning environments adapted to the specific problem contexts are key. However, even though mobile technologies have provided a practical platform for contextual learning, there is still no significant pedagogical change in terms of social media empowering students' social innovation skills [41,42]. Perez found that $80 \%$ of millennials use social media daily, thus, the adoption of such tools in education seems imminent [43]. In an increasingly networked society, where proximity is not anymore relevant for the social organization [44], social media can be a powerful tool for collaborative learning and production. Cochrane and Rhodes concluded that mobile learning provides a fruitful student-directed collaboration enabled by the unique features of social media [45]. A study by Smith [30] envisions architecture students as possible prodigies of the planning workshops, however, assigns them a marginal role in drafting or "innovation through drawing". Ham and Schnabel make only one short reference to students tapping into their social capital with online acquaintances via Chat, Facebook, YouTube, etc., and using this collective intelligence to enlarge their knowledge [46]. In the bigger context of achieving the sustainable development goals set by Agenda 2030, it is crucial to advance the research on how students' agency, creativity, leadership, and engagement can be leveraged for making better and more sustainable places. 
Tracey and Stott (2017) defined three types of social innovators: social entrepreneurs, social intrapreneurs, and social extrapreneurs [14]. Social entrepreneurs design and grow forprofit or non-profit "hybrid organizations", to address a certain social challenge, such as the microfinance endeavors of Muhammad Yunus [47], while social intrapreneurs address social challenges as commercial opportunities from inside for-profit organizations [48]. In this research, the focus is on the third and least explored type of social extrapreneurs defined by Algoso as "extrapreneurs that create things in a space that transcends any one agency. Extrapreneurship is a partnership approach that goes beyond co-ordination or co-branding. It starts with the network and leverages [resources] ... to create a disproportionately greater development impact" (cited from Tracey and Stott, [14]). Social extrapreneurs, in the context of this research, were students that officially belong to a certain institution but operate between different organizations and communities, combining ideas and resources to create new support mechanisms for social change. They understand that a public place is both a social and physical creation that should be a product of collective stakeholders' imagination about the place's qualities. A collaborative educational method using social media could enable architectural students as content producers and community generators. In this context, the professor's role would be to guide the process where "learning happens in part through a kind of reflective practicum, but here the reflection comes from being embedded in a social milieu supported by both a physical and virtual presence and inhabited by both amateurs and professionals... Social software enables communities to form and find each other, to learn through remixing, tinkering, and sharing artifacts using the rich media now available" [49].

\subsection{Research Questions and Objectives}

In emerging regions where resources are scarce, social and spatial inequalities pronounced, and activism almost non-existent, how can we leverage the digital natives' widespread use of social media as a resource for social innovation in placemaking? How effective are activism and virtual volunteering as tools to develop a horizontal network of stakeholders for an inclusive and non-oppressive public space design? Based on the idea that a networked society is creating a "shadow structure" that erodes the traditional institutional effectiveness and legitimacy [44], the hypothesis is that digital communication platforms can improve the traditional participation workshops and develop better-suited mechanisms for a quality place production in segregated societies. Thus, the research objectives were to design and test an alternative educational method to stimulate social innovation in placemaking using collaborative digital platforms in the undergraduate architecture studio. Open communication and knowledge-sharing using social media were considered crucial premises for the effectiveness of such a method. The assessment of the method was based on a comparative analysis of results between a study group where the method was first implemented and a previous study group where social innovation was not an objective. The benefit of such a method was foreseen in the potential for maximizing the creative power within the whole community in imagining a better future, thus strengthening the capacity for evolutionary resilience.

\section{Materials and Methods}

The ubiquitous social media has opened various possibilities for social innovation and activism in placemaking. To explore the idea of students as prodigies in innovative placemaking processes, the conceptual framework for the new educational method was based on the concept of social extrapreneurship, using collaborative digital platforms.

\subsection{Carrying Out the Investigation}

In 2009, Nambisan [50] defined three types of collaboration platforms necessary for the social extrapreneur to make innovation happen: exploration, experimentation, and execution (Figure 1). 


\begin{tabular}{|c|c|c|c|}
\hline $\begin{array}{l}\text { collaborative plat- } \\
\text { forms for social } \\
\text { extrapreneurs }\end{array}$ & EXPLORATION & EXPERIMENTATION & EXECUTION \\
\hline $\begin{array}{c}\text { PLATFORM } \\
\text { GOAL }\end{array}$ & $\begin{array}{c}\text { Bring together diverse } \\
\text { stakeholders and define } \\
\text { social problems }\end{array}$ & $\begin{array}{l}\text { Propose solution tem- } \\
\text { plates and test them in } \\
\text { near-real world" context } \\
\text { created by social media }\end{array}$ & $\begin{array}{l}\text { Develop final solution } \\
\text { templates and dissemi- } \\
\text { nate them through social } \\
\text { media }\end{array}$ \\
\hline $\begin{array}{l}\text { THE ROLE OF } \\
\text { AN EXTRAPRE- } \\
\text { NEUR }\end{array}$ & $\begin{array}{l}\text { Create a horizontal net- } \\
\text { work of stakeholders and } \\
\text { develop social media fo- } \\
\text { rums for interaction }\end{array}$ & $\begin{array}{l}\text { Include stakeholders' } \\
\text { feedback in the design } \\
\text { and provide a safe envi- } \\
\text { ronment for remixing, } \\
\text { tinkering, and sharing } \\
\text { artifacts }\end{array}$ & $\begin{array}{l}\text { Facilitate sharing of solu- } \\
\text { tions and provide follow- } \\
\text { up steps for implementa- } \\
\text { tion and management }\end{array}$ \\
\hline OUTCOMES & $\begin{array}{c}\text { A shared understanding } \\
\text { of the problem and de- } \\
\text { fining a common goal for } \\
\text { the project }\end{array}$ & $\begin{array}{c}\text { Collective evaluation of } \\
\text { possible solution strate- } \\
\text { gies }\end{array}$ & $\begin{array}{l}\text { Providing a solution to } \\
\text { the social problem and } \\
\text { consolidating the social } \\
\text { innovation process }\end{array}$ \\
\hline
\end{tabular}

Figure 1. Three types of collaboration platforms for social innovation, based on Nambisan [50] (p. 47).

The exploration platform's goal is to bring together diverse stakeholders so that they can more accurately define socially constructed problems. Once the stakeholders develop a shared understanding of the problem, they can start working on possible solutions through the experimentation platform. An experimentation platform is an impartial setting where possible solutions can be tested in a "near-real world" context. Nambisan claims that as social innovations become more complex, experimentation converts into a basis for effective problem-solving. Finally, the execution platform rolls out the findings and distributes template solutions. The templates capture the fundamental elements of the solution and help stakeholders coordinate their strategies.

The collaboration platforms in this research were used in the context of problem-based learning as a mechanism to stimulate, contextualize, and integrate learning through independent research and knowledge application on real-world problems. Problem-based learning was grounded on the premise that knowledge is socially constructed in communities of practice. The features of the problem-based learning defined by Newman are the teacher as a facilitator, explicit process to facilitate learning (critical feedback), solving realworld problems, small group work, and comprehensive assessment [51]. Unlike the three platforms that form separate stages of development, the features of problem-based learning are cyclical and iterative strategies implemented consistently throughout the process. They aimed to promote the development of students' awareness, systemic thinking, critical thinking, creativity, problem-solving, strategy, self-directed learning, decision-making, and interpersonal skills. For these skills to be acquired, the curriculum has to be cumulative, integrated, progressive, and consistent [52].

\subsection{Design of the Method}

The duration of the architectural studio course is $90 \mathrm{~h}$ of synchronous work (classwork) and $90 \mathrm{~h}$ of asynchronous work (homework). The time was divided equally between the three collaborative platforms of exploration, experimentation, and execution. Each platform phase included specific tasks to reach the predefined aim, with the help of three didactic methods: research, applied knowledge, and networking. The first exploration platform phase $(30 / 30 \mathrm{~h})$ was dedicated to research to define the problem and key stakeholders in the placemaking process; the second experimentation platform phase $(30 / 30 \mathrm{~h})$ was dedicated to applied knowledge in collaborative place design through experts and stakeholders' feedback, and the third experimentation platform phase $(30 / 30 \mathrm{~h})$ was dedicated to networking and dissemination of the final solution templates for aligning stakeholders' interests. 
While research and applied knowledge are already well-established didactic methods [53], networking was the novel element in this context that was used to involve local stakeholders in defining the problem and testing design prototypes. The networking required students to communicate ideas through different social media platforms and find socially constructed solutions. Its didactic power was foreseen in enriching the traditional unidirectional transition of information from teacher-student to collective-student, in which the teacher is a collaborator and facilitator in the design of the social innovation project. Therefore, networking is a funnel for inclusion in the imagination of place but also a tool for reflection and re-evaluation of the proposed technical concepts conceived in the professional domain of the workshop. Networking not only included students and local citizens but also teachers, the municipal planning authority, and experts in other fields. Thus, networking in this research was key to forming horizontal collaborative networks of various local agents as a base for future place improvements, and its intensity increases in every consecutive phase. While the first phase aimed only at setting the platforms and identifying audiences, the second phase already actively engaged partners in discussing solutions strategies through an online survey and conferences. The third phase depended heavily on networking to assess proposed solution templates and get meaningful insights through a process of "digital tinkering". This process implied posting visual templates of place design on social media platforms as triggers to unleash the creative power of local agents. The additional benefit of networking in this phase was in encouraging people to bond over the activity of place re-imagination.

The course method was designed to respond to the systemic and relational nature of the place-making processes in which small interventions can have implications on larger scales. Therefore, three different territorial scales were tackled in each platform phase.

The exploration platform phase focused on the analysis of socio-demographic, economic, natural, and urban form indicators at the municipal level (or XL scale) and the site level-within a $2 \mathrm{~km}$ buffer zone around the site (or L scale). The main materials for this phase were quantitative and qualitative data collected from national, state, and municipal open databases, as well as Google Earth and social media outlets. The students analyzed 14 census database documents (shapefiles from INEGI-National Institute of Statistics, geography, and Informatics of Mexico, 2015) and three official planning documents (the City Prosperity Index report, 2018 [54], as well as the Municipal Development Plan 2015 and the State of Mexico Development Plan 2015), for the extraction of territorial data. The main instrument for the analysis was QGIS, which was used to correlate different indicators and produce interpretative maps of various aspects of the territoriality, including the following:

- $\quad$ Productive Landscape Map (land uses + natural resources + economic dynamics);

- $\quad$ Social Ecology Map (social dynamics + public space + services);

- Cultural Landscapes Map (nature + socio-economic dynamics + heritage and meaning);

- Urban Landscape Map (figure/ground diagrams + building typology + marginalization).

Online conferences were arranged with experts from the municipal office to help students analyze the regulation, land-uses, and mobility patterns.

The experimentation platform phase was focused on the design of spatial strategies for the place re-imagination and the Master Plan (or the M scale), where accessibility, zoning, and functional connections of the place were designed. To understand the patterns of use, the appropriation of space, and needs of locals in a public place, the main instrument was an online survey that the students adjusted based on the instruments used in a previous research project by Pérez-Paredes, 2019 [55] (full survey in Appendix A). The students researched how to design the structure of a successful survey, how many parts the survey should have, how many questions, and what type of answers to look for (open-ended, numerical, Likert scale). The survey was designed in Google Forms and consisted of 49 questions that contained four sections: (1) The first aimed at revealing the demographic profile of the respondent (questions 1-11); (2) the second aimed at uncovering habits related to the use of public spaces (questions 12-24); (3) the third aimed at deciphering local social 
relations (questions 25-34); and (4) the fourth focused on specific public space features considered important or key for the respondent in public space design (questions 35-49).

The survey was shared through students' social networks, such as Twitter, WhatsApp, Facebook, and personal emails. The fact that students are locals aided the communication and eased barriers of introduction. The survey results quantity and quality were essential for the assessment of the potential of the method for social innovation. The conclusions obtained from the analysis of the results formed the base for the proposed spatial strategies and Master Plan in this phase. The social network platforms (for locals) and evaluation sessions (for experts) were the main instruments to get feedback from partners on the proposed solutions, which enabled the students to make adaptive changes to the design.

Finally, the execution platform phase was focused on the architectural intervention inside the site, which was a surgically planned small-scale intervention, to achieve at least one of the proposed spatial strategies of the experimentation phase. The students developed architectural plans with Autocad 2018 (v. 22.0) and Revit 2018 (v. 1.3.4) and renders with the Adobe CS 6 (v. 6 software). The visuals were used for the communication of the solution templates through Facebook and Behance platforms. Therefore, the reflective aspect of the last work stage was crucial to close the loop of different scales started with the urban analysis and understand the interrelationships in socio-environmental systems, through the implications of small-scale interventions in a larger context.

Figure 2 presents the structure, objectives, and didactic methods, as well as the tasks, tools, and expected outcomes of the collaborative educational method for social innovation design specifically for the course.

\subsubsection{Assessment of the Method}

The method's potential in public space design was assessed based on parameters that reflect social extrapreneurs innovation and problem-based educational achievements in project results.

The parameters for the assessment of social innovation included the following:

- Ability to form partnerships and cooperation-Were students able to form partnerships with local actors and use the partnership to develop and better the proposed solutions?

- Social media incidence-How often were social media tools used for communicating ideas, and how often was the product adjusted according to social media feedback?

- Combine ideas and resources to create new support mechanisms for social changeHow often do students use self-initiated activism during the project development to obtain data or re-evaluate outcomes? How often do they use digital volunteering to promote or advance the project (e.g., civic journalism, crowdsourcing, e-learning, and mapping)?

- Focus on reducing inequality-Does the project focus on vulnerable or discriminated groups? Does the project improve access and mobility? Does the project reflect the concept of "right to the city"?

The parameters for assessing the educational value included the following:

- Project cohesion-Are the conclusions of the urban analysis tackled in the architectural intervention? In other words, is there a cohesion between the project development phases?

- The originality of products-Do the project outcomes bring about novel and fresh solutions in urban and architectural design? Do the outcomes represent fresh design approaches while following planning norms and established standards?

- The self-satisfaction of project achievements-Do the students feel satisfied with the personal and professional skills they acquired during the course?

- A better understanding of sustainable development-Do the students feel they understand better the complexity of sustainable development at the local level? Do they perceive better the link between sustainable development and ethics in the profession? 
The above parameters were weighted from 1 (very low) to 5 (very high). The socialinnovation parameters were evaluated by the professor in charge of the course (the author of this paper), based on the number of people reached with posts, the quality of interaction and data collected, and the hands-on involvement in defining and solving the problem. The project cohesion and originality of products were co-evaluated by the professor in charge of the studio and the invited external experts, one of which was the municipal planning official (the training partner for the course). The data regarding satisfaction from the course and understanding of sustainable development were gathered with a survey designed by the professor in charge at the end of the course. As a control variable, a previous studio group where the method was not applied was evaluated with the same parameters and identical self-evaluation survey. Both groups worked on the same public space design, making possible the comparison of product quality and impact.
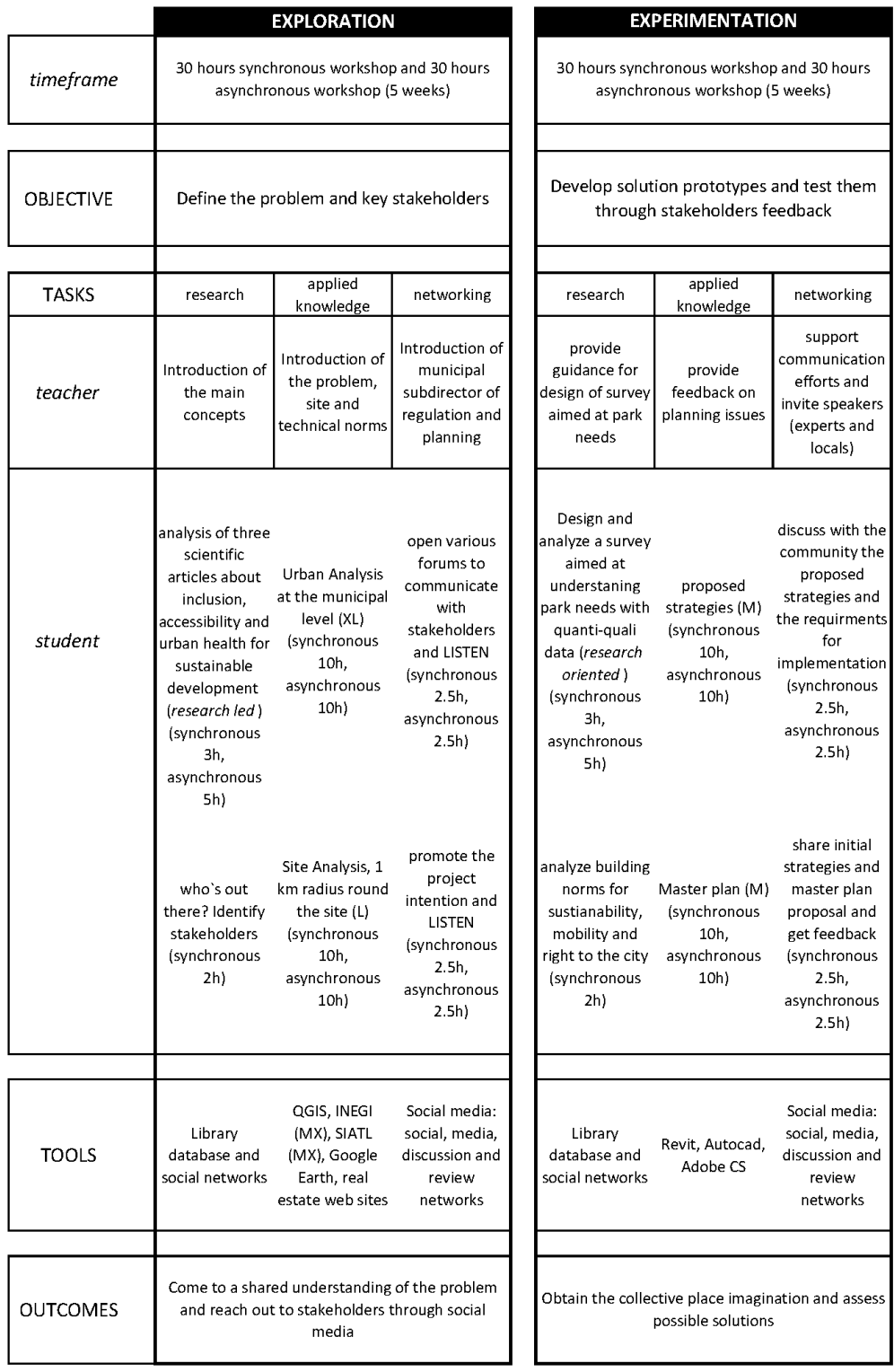

\begin{tabular}{|c|c|c|}
\hline \multicolumn{3}{|c|}{ EXECUTION } \\
\hline \multicolumn{3}{|c|}{$\begin{array}{l}30 \text { hours synchronous workshop and } 30 \text { hours } \\
\text { asynchronous workshop ( } 5 \text { weeks) }\end{array}$} \\
\hline \multicolumn{3}{|c|}{ Build and dissiminate solution templates } \\
\hline research & $\begin{array}{c}\text { applied } \\
\text { knowledge }\end{array}$ & networking \\
\hline $\begin{array}{l}\text { Provide } \\
\text { feedback for } \\
\text { possible } \\
\text { intervention } \\
\text { impact and } \\
\text { implications }\end{array}$ & $\begin{array}{c}\text { provide } \\
\text { feedback on } \\
\text { design issues }\end{array}$ & $\begin{array}{c}\text { invite local and } \\
\text { external } \\
\text { evaluators }\end{array}$ \\
\hline $\begin{array}{c}\text { Analyze } \\
\text { feedback of } \\
\text { proposed } \\
\text { strategies in the } \\
\text { context of } \\
\text { analouge cases } \\
\text { (research- } \\
\text { based) } \\
\text { (research } \\
\text { oriented) } \\
\text { (synchronous } \\
\text { 3h, } \\
\text { asynchronous } \\
\text { 5h) }\end{array}$ & $\begin{array}{c}\text { Architectural } \\
\text { Intervention } \\
\text { Porposal (S) } \\
\text { (synchronous } \\
10 \mathrm{~h}, \\
\text { asynchronous } \\
10 \mathrm{~h} \text { ) }\end{array}$ & $\begin{array}{c}\text { facilitate the } \\
\text { diffusion of } \\
\text { solution } \\
\text { template } \\
\text { (synchronous } \\
2.5 \mathrm{~h}, \\
\text { asynchronous } \\
2.5 \mathrm{~h} \text { ) }\end{array}$ \\
\hline $\begin{array}{c}\text { correlate data } \\
\text { from scientific } \\
\text { papers, survey } \\
\text { and social } \\
\text { media to get } \\
\text { meaningful } \\
\text { inputs } \\
\text { (synchronous } \\
\text { 2h) }\end{array}$ & $\begin{array}{c}\text { Impact Analysis } \\
\text { (S, M, L, XL) } \\
\text { (synchronous } \\
10 h, \\
\text { asynchronous } \\
10 h)\end{array}$ & $\begin{array}{c}\text { provide } \\
\text { resources that } \\
\text { adopters can } \\
\text { use to manage } \\
\text { the project } \\
\text { impact } \\
\text { (synchronous } \\
2.5 \text {, } \\
\text { asynchronous } \\
2.5 \text { ) }\end{array}$ \\
\hline Excel & $\begin{array}{l}\text { Revit, Autocad, } \\
\text { Adobe CS }\end{array}$ & $\begin{array}{l}\text { Social media: } \\
\text { social, media, } \\
\text { discussion and } \\
\text { review } \\
\text { networks }\end{array}$ \\
\hline $\begin{array}{r}\text { Produce soluti } \\
\text { horizon }\end{array}$ & $\begin{array}{l}\text { in templets and } € \\
\text { al collaborative }\end{array}$ & $\begin{array}{l}\text { stablish strong } \\
\text { letwork }\end{array}$ \\
\hline
\end{tabular}
and possibilities

Figure 2. The collaborative educational method for the collective imagination of public space, based on social innovation platforms. 


\subsubsection{Study Participants}

The study had 22 core participants, of which 17 were students enrolled in the studio course, one professor in charge of the course and the study, and four external experts. The student body comprised seven male and ten female students who were 21 and 22 years old and were, at the time, enrolled in the 8th semester of their undergraduate study. The professor in charge of the course was a 43-year-old female research professor who designed the study.

In the exploration platform phase, the students formed eight groups and performed the urban and site analysis, using official documents to gather quantitative and qualitative data. Two of the external experts gave online conferences, where they shared their knowledge of the local socio-spatial conditions, regulations, and the municipal development plan. Both experts are locals that work in the municipal planning department and are civil engineers. One of them is a 37-year-old female Deputy Director of Urban Planning and Regulation for the municipality, while the other is a 38-year-old male consultant on mobility and public space design.

In the experimentation platform phase, all 17 students worked as a team to develop and distribute an online public survey under the supervision of a 42-year-old female invited expert on the appropriation of public space who leads the Citizen Socio-Environmental Lab and lives in the same municipality. The digital survey was adapted from a previous research project [55]. The survey received 126 responses from local people who are considered collaborators for the project. A majority of respondents belong to the largest municipal age group of 30-50 years old, where $45 \%$ are responsible for a minor under 16 years of age and $25 \%$ have children under 6 years. Most of them work paid jobs, and $76 \%$ own the house where they live. Nevertheless, less than $20 \%$ were born in the municipality, and less than $5 \%$ have parents born in the municipality, which reflects the recent development of the municipality. The demographic data that did not reflect a municipal average was concerning the educational level since $70 \%$ of respondents to our survey have a university degree. In the municipality, on the other hand, only 4 in 10 people have some kind of higher education degree (INEGI, 2015). The students considered this was because their circle of acquaintances usually includes people of the higher middle class or other members of the university community. In this phase, the students in eight groups developed eight distinct design strategies for the park's rehabilitation based on the urban and site analysis made in the exploration phase and the survey results. The external adviser, who collaborated with the groups to develop ecological restoration strategies, was a 36-year-old male Landscape Architect who teaches at the same school.

In the execution platform phase, the four external experts were invited to online conferences where they revised and evaluated the proposed design projects from regulation, budget and implementation challenges, and socio-environmental perspective and gave critical feedback for the design adjustments. Finally, the eight student groups shared the design templates on social media through the Facebook and Behance platforms. The templates on Behance were viewed 810 times and evaluated by 216 people, while the FB page reached 170 people. These locals were considered collaborators in the project since their feedback was crucial for the evaluation and alignment of the placemaking strategy.

\subsection{The Context of the Study}

\subsubsection{The Institutional Context}

The collaborative educational method was implemented in Tec de Monterrey's undergraduate architectural studio course, held in the Campus State of Mexico in the municipality Atizapán de Zaragoza. Tec de Monterrey is currently implementing a new higher education Model Tec21 that aims to free the full potential of young adults and support them in becoming agents of change in unpreceded times full of uncertainties, challenges, and potentials. One of the basic requirements of Tec21 is to engage the students in problem-based learning, utilizing modern technological tools for the greatest social impact and community benefit. 


\subsubsection{The Case Study Area}

The municipality Atizapán de Zaragoza is located in the northern periphery of the Mexico City Metropolitan. It is a commuting suburb [56], with a consolidated urban area of $91 \mathrm{~km}^{2}, 489,937$ residents, and a population density of 5635.7 people $/ \mathrm{km}^{2}$ (INEGI, 2015). It has a strong spatial and social segregation, housing some of the most affluent and most marginalized neighborhoods in the metropolitan area. The case study for the studio was the park Mexico Nuevo that is located in the central zone of Atizapan, in the middle-class neighborhood of Mexico Nuevo with 8949 residents (INEGI, 2015). It was started as a strategic project of the municipality in 2015 when the large sports areas in the south were developed. The park also has two additional smaller areas on the north that are spatially and functionally disconnected from the sports area. The park was left unfinished, with the monumental main entrance still wrapped in bob wire, and receives very little maintenance. Nevertheless, due to its size and some opportunities for recreation, such as the football and basketball fields, running track, and a skate park, it still attracts local visitors. However, since there is no adequate lighting, no security protocols, no organized activities or social programs, nor parking or other accessibility infrastructure, it is considered unsafe for women and girls, children, and older adults.

\section{Results}

In this section, the results of the workshop in each phase, namely exploration, experimentation, and execution, and the assessment of the method are presented. The method was applied in the Integrated Projects II course, taken by 17 students, in the fall period of 2020 (11 August-9 December).

\subsection{Phase 1-Exploration}

The first results presented an urban analysis of the socio-economic, natural, and built environment conditions. The students also analyzed the main risks and environmental threats, as well as tangible and intangible heritage as a resource for community development. The urban analysis was successful in describing the key position of the park in the larger urban structure, its good connectivity to arterial roads, and the demographic profile of municipal residents. The citizens outside of Mexico Nuevo were considered by students as potential weekend visitors or secondary agents, as opposed to the 8949 locals that represent everyday users most invested in the park's development and maintenance.

Based on the urban analysis, the students elaborated interpretative maps that visualized the conclusions for communication purposes. The maps showed the staggering social and spatial inequalities between the affluent western neighborhoods and the northern marginalized ones. The abundance of green public areas in the affluent areas and the lack of accessible public parks in the poorer ones are represented, as well as the different social interactions in those zones. One interesting conclusion that the maps brought to light is that even though the affluent zones have abundant green areas and well-maintained public zones, they are rarely used. On the other hand, the dense and impoverished zones of the north demonstrate a lively public life on the streets. The maps were shared through the FB page "Espacio Publico Atizapan" created by the students. It was observed that these types of research maps were more appreciated by professionals, such as planners, architects, and sociologists, than locals since most of the comments we received were from our professional partners. The municipal representative commented that the interpretative maps had a powerful impact on internalizing and communicating key issues for sustainable local development.

Next, the students focused on the site analysis, which was bounded to a buffer of $2 \mathrm{~km}$ around the park. The students were able to decipher the immediate physical context of the park, define the demographic profile of the local user in walkable proximity or prime-agents, and identify key problems related to the park usage. The conclusions helped achieve the objective of the first exploratory phase to identify key stakeholders and define the problem of the study area in the following: 
- Lack of safe access;

- Lack of spatial and functional connection between the three areas of the parks;

- Insecurity due to lack of lighting or security protocols;

- Lack of urban furniture (sitting, garbage cans, playground, etc.), lack of sanitary infrastructure and drinking water, and lack of shade;

- Lack of social programs or activities;

- Environmental pollution;

- Lack of maintenance of buildings and landscaping.

\subsection{Phase 2-Experimentation}

\subsubsection{Survey Results}

The survey got 126 responses, which for a municipality of 489,937 residents represents a satisfactory sample size with a margin of error of $9 \%$. The survey was analyzed by the students with mixed methods, using statistical analysis for the quantitative data, text mining for the open-ended questions, and attitude scaling with the Likert scale.

In terms of habits of using public spaces, the results showed that $41 \%$ of people do not have a park in walkable proximity to their house-evaluated as an open public space further than $10 \mathrm{~min}$ walking. During weekdays, the place for exercise and recreation was described by the majority as being the gym $(30 \%)$, followed by a local park $(22 \%)$ and a commercial center (18\%). During weekends, visits to commercial centers $(34 \%)$ and regional parks $(20 \%)$ increased significantly, while visits to the gym $(14 \%)$ and local park $(15 \%)$ decreased. These results show a pattern of suburban lifestyle that considers the private shopping mall as a "public place" that receives the most frequent visits. Most respondents pointed to the security issues, distance, and bad maintenance of public places as the main reasons for the infrequent visit.

Regarding social relations, most of the respondents felt they know their neighborhood very well (average score of 7 on the Likert scale of 1-10). Nevertheless, the majority (39\%) have no relations with their neighbors, while $37 \%$ only communicate with their neighbors for some urgent local issues. The majority $(60 \%)$ do not belong to any civil or community organization. The students reasoned that the lack of community is probably due to the lack of history and cultural identity of the municipality. The majority of respondents also think that the maintenance of public places should be an exclusively municipal authority obligation, while very few feel that self-organized citizens should manage public places.

The students described the results regarding preferences in public space design as unexpected (Figure 3). While the expectations were that a fence or enclosure of public space as a measure to provide security would be one of the top preferences, in fact, less than half of respondents considered it necessary. The aspects of park design that were most valued were illumination, cleanness, maintenance, and garbage cans. Following in importance are surveillance, toilets, and drinking water, as well as shade. The aspects of product vending, rent of bicycles, and free Wi-Fi were not considered important. The students reasoned that the aspect of free Wi-Fi was probably not considered important from middle-income class respondents since they have other ways of obtaining internet access.

\subsubsection{Spatial Strategies}

The students used the conclusions from the survey to develop user-centered spatial strategy proposals for the park's rehabilitation. The proposals included careful consideration of key problems of the built environment related to accessibility, lack of urban furniture, and safety of vulnerable groups-women and girls, children, and older adults. The strategies were oriented towards improving the night lighting, safe crossings, development and maintenance of sanitary facilities, and seating and hammocks, as well as cleaning of the nearby stream. The spatial strategies were published on the FB page and diffused through the students' social networks. In our case study, the networking showed that local stakeholders give priority to the social aspects of the place-making over environmental 
improvements. Examples of the received feedback included the following (translated from Spanish, by the author):

"I want to go to the park with my kids, but there is nothing to do there. My kids run for a while but then they get bored, I wish there would be some playground, games, or activates for them ... also there is no place to sit ... " (a 35 years old mother of two children, aged 13 and 3)

"I wish there would be some sports club for girls or places where I can play ... once I went by myself to play football and some boys told me to leave because football is a boys 'game, one of them grabbed me by my hair and dragged me out ... " (a 14 years old girl)

"I sometimes go to the park with my daughter. But she is very busy so we do not go often ... I cannot go by myself cause people drive like crazy here, nobody stops and I cannot cross the street, I am afraid they will run me over... also there is no smooth walking path inside the park, the terrain is inclined with a lot of rocks and holes, I can easily fall so I prefer to stay home... " (a 75 years old man)

According to the received feedback, the spatial strategies were adjusted by the students to include more functions for vulnerable groups instead of environmental improvements. For example, the natural filtration system for the nearby stream was replaced with a children's playground in subsequent Master Plans. Special attention was placed on improving crossings and opening new entry points for better accessibility. The existing infrastructure was rescued in the new Master Plans, however, the large sports facilities were injected with new cultural and recreational functions, such as yoga, dance, karate, art classes, etc., that will share the same space by time-sharing schemes. In the abandoned zones, new functions oriented towards the community were proposed, such as a learning zone, communal garden, an orchard, and a picnic area. The comments from the municipal official clearly showed that there is no available municipal budget for urban or architectural interventions in the park, although it was mentioned that a "good plan" could be considered by the new mayor (2021) as part of his/her four-year agenda. When the students asked what is a "good plan" the official answered: "a plan that will benefit the majority of people in the neighborhood, that will not cost the municipality to build, and that will ideally be managed by communal organizations" (Asociación de colonos in Spanish).

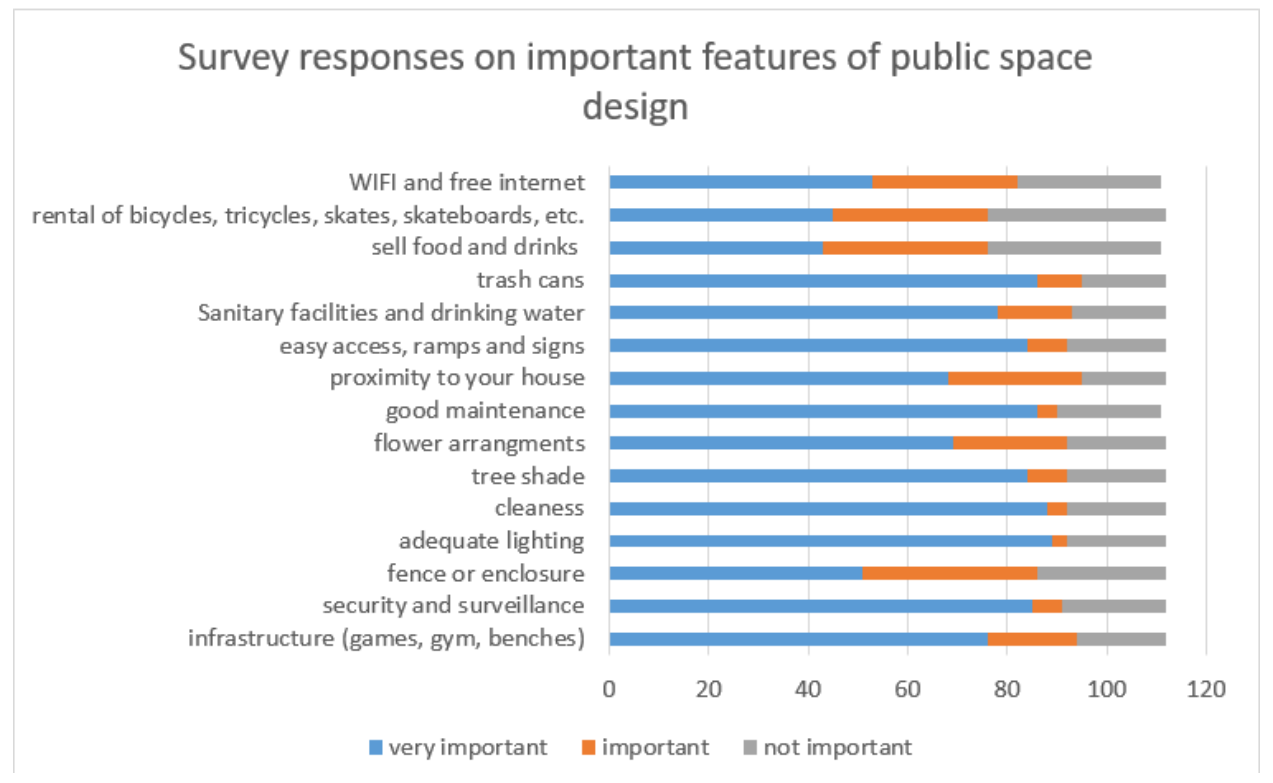

Figure 3. Analysis of survey results. 


\subsection{Phase 3-Execution}

According to the received feedback, the students turned to explore tactical urbanism as a strategy for architectural interventions. Many of the groups considered that through the idea of regenerating the park, the community could come together and build their playgrounds or recreational areas with recycled materials such as old tires, concrete tubes, sand, etc. The students considered that a self-constructing strategy could contribute to community building and appropriation of the public space, where new values would be formed through the joint effort with a common goal of improving this public place.

Based on this idea, architectural templates were proposed for specific park areas, such as a children's playground and learning/recreation zone (Figure 4), which focused on reused elements that could be combined in different ways. Finally, the execution phase was concluded by posting the proposed template solutions as visual communication tools on the platform Behance. The platform gives the option for a Mood board to be created where all eight templates designs from the eight groups who worked on the project were attached (https: / /www.behance.net/collection/180635185/AD20-CEM-Pi2-G2-AKrstikj, last accessed 2 March 2021).

The Behance platform was promoted through the facebook page "Espacio Publico Atizapan" and students' networks to ask locals to vote for the best solution (Figure 5). The design proposal shown in Figure 4 was among the best-received solutions.

Even though the course finished the last week of November 2020, the students felt very engaged with the project and are continuing to work with locals on adjustments and impact analysis. Several students engaged their family businesses to provide cost analysis for some interventions such as public lighting and urban furniture. In this aspect, students act as self-organizing agents that can generate larger networks of stakeholders. The goal is to present the proposal to the local government through the local community association and with the help of the municipal official who participated in the design.

\subsection{Assessment of the Potential of the Method for Social Innovation}

The outcomes of the novel method were evaluated according to the eight parameters of social innovation and educational value described in Section 2.2.1. Through a comparison of the results with a group where the novel method was not implemented, the outcomes showed that the novel method does indeed foster social innovation in place production (Figure 6). The method improved the social construction of solutions with the tools based on social media that fostered participation and inclusion in the collective imagination of "what the place could be". In fact, one of the most remarkable results of the new method was the potential of forming horizontal collaborative networks between students, experts in different fields, local authorities, and community actors and utilizing this collective wisdom to produce better context-based places. Nevertheless, the inclusion of marginalized groups remains questionable and new tools are needed to promote better inclusion of this group in the process. The spatial strategies, the master plan, and the architectural interventions responded much better to the pre-existing urban conditions and social needs. The students also felt more engaged in the process and enjoyed working on social problems. However, the overall understanding of the project's impact on local sustainable development remained weak. Additional effort is needed to clarify this aspect to students in future studios. 


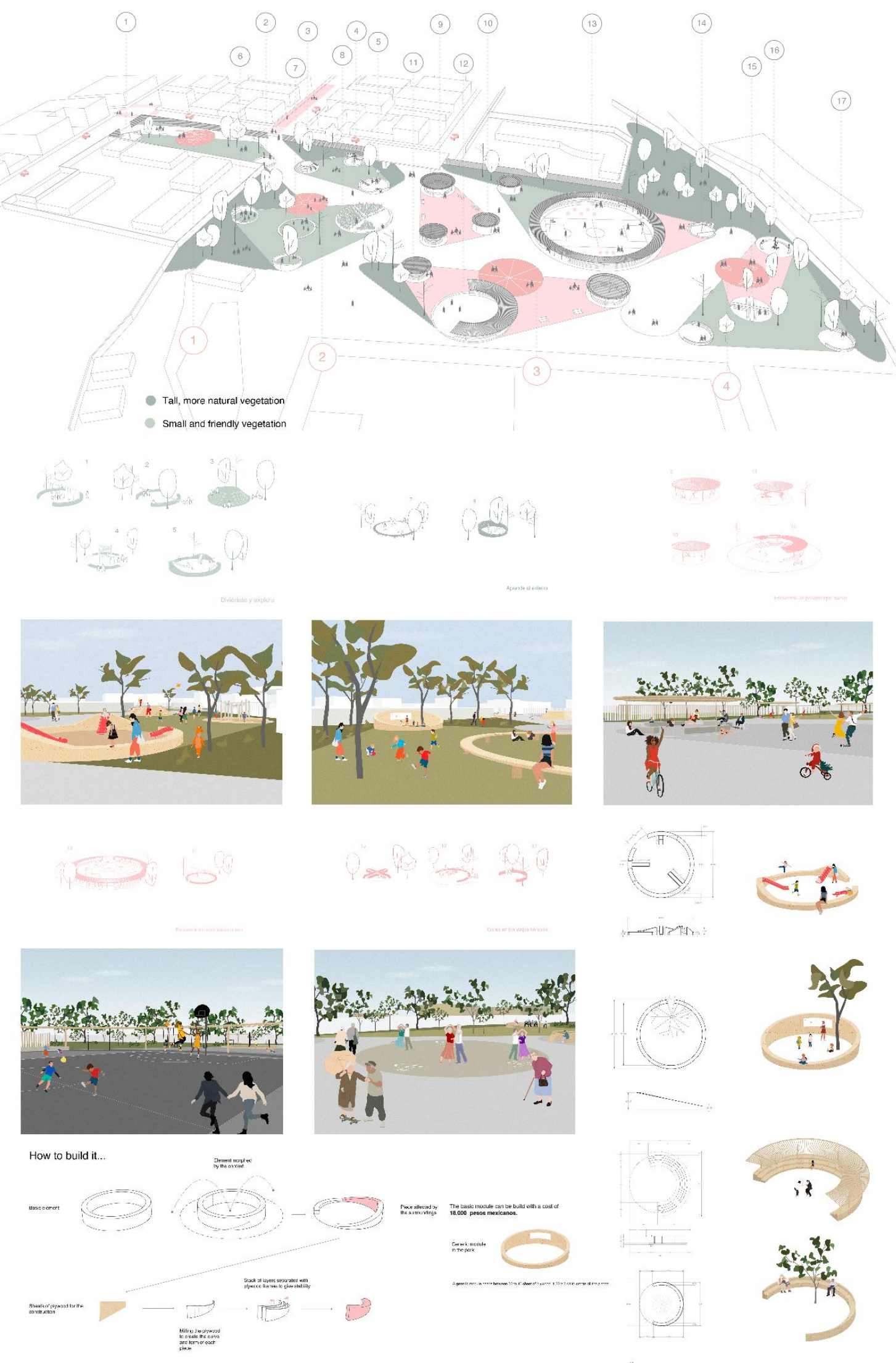

Figure 4. Learning/recreations zone, by Gerardo Yabur and Abigail Zavaleta. 


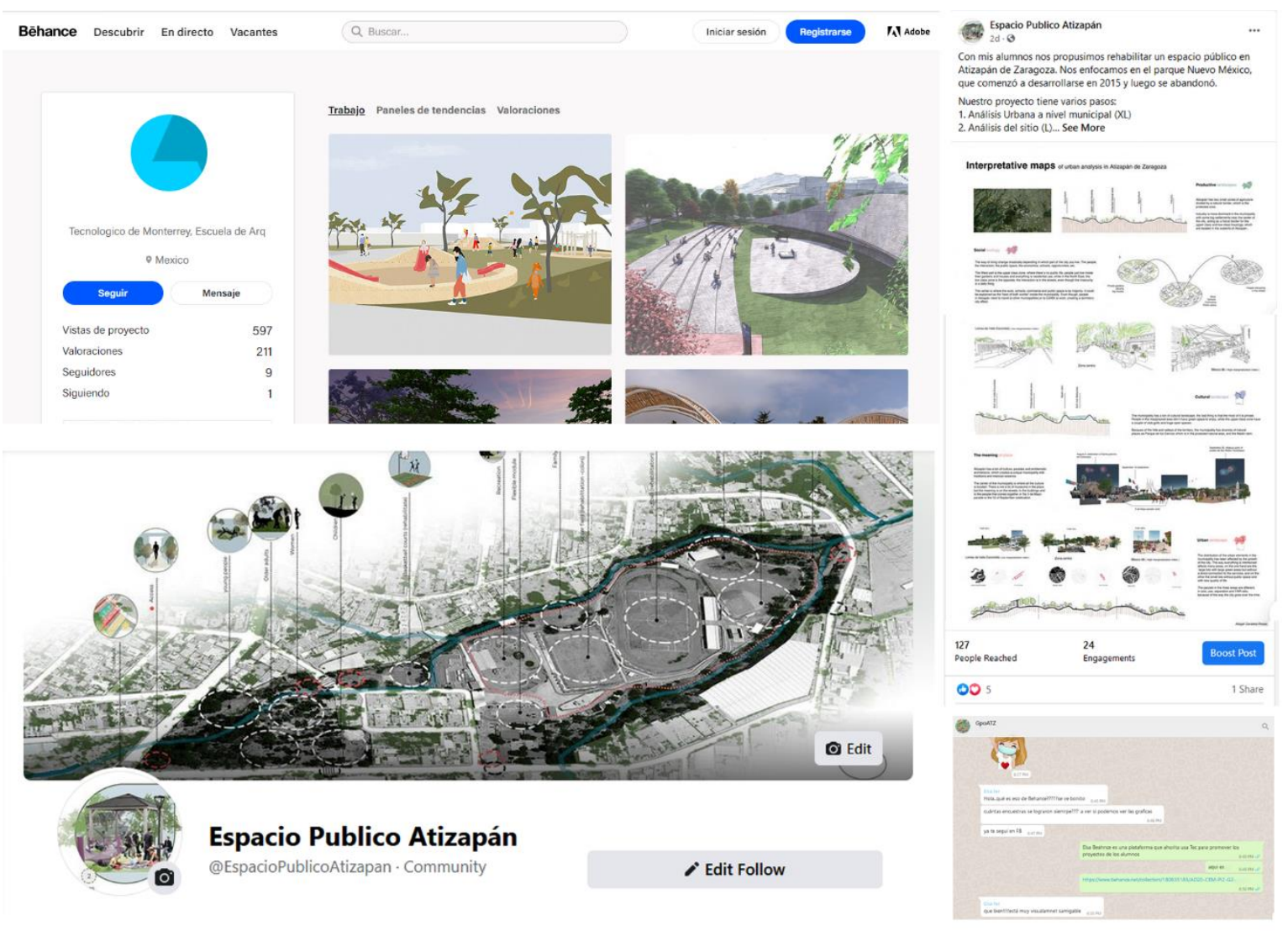

Figure 5. Social media platforms used for the dissemination of design templates in the execution platform phase.

Assessment of the method's potential for collective place imagination

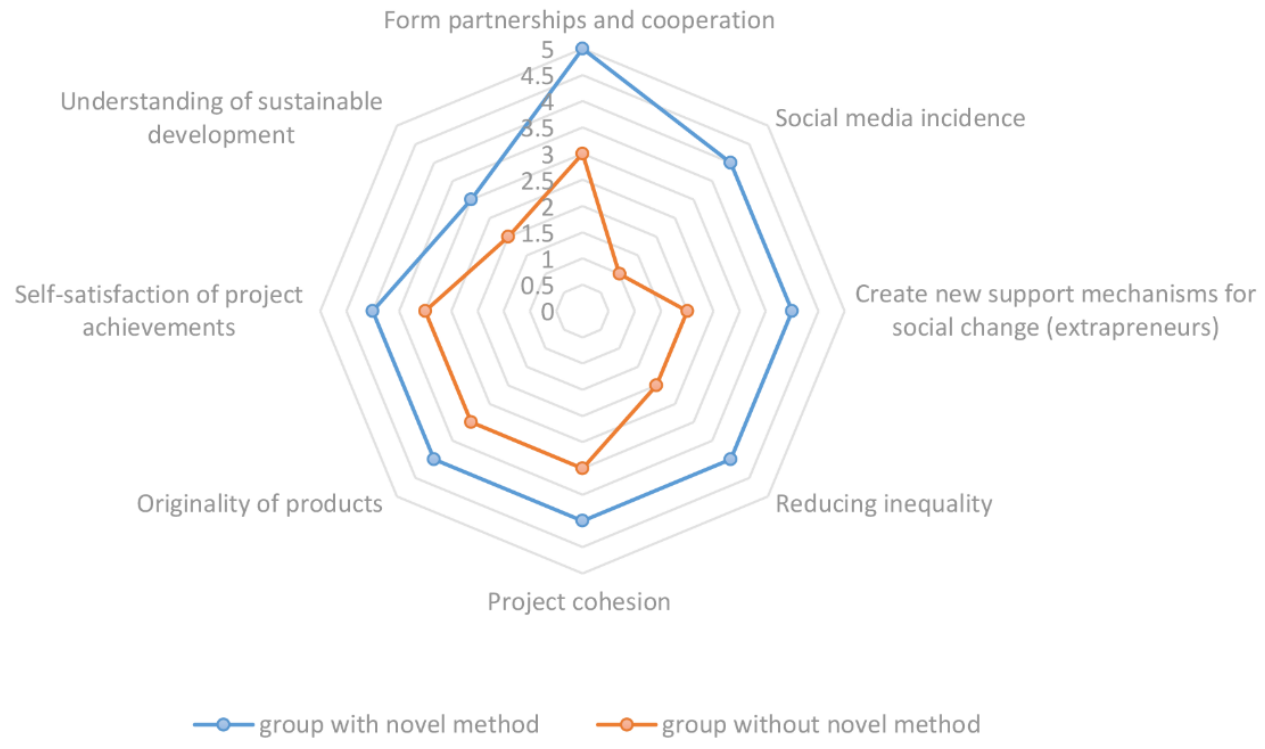

Figure 6. Assessment of the potential of the method for social innovation. 


\section{Discussion}

"Architecture, more than any other art form, is a social art and must rest on the social and cultural base of its time and place".--Samuel Sambo Mockbee

The implication is substantial: The novel method provides an approach "to assist students in enabling them to make decisions about what value means in architecture" [57]. By enabling critical thinking, setting the base of action on social justice, and encouraging the use of social media throughout the design process, the method turns students into active agents of social change and provides an important contribution to the necessary, but still uncharted, paradigm shift in architectural education from object to the peopledriven design. Moreover, by forming horizontal networks of stakeholders, the students were able to develop a new alternative process of place production that responds to the challenges of local sustainable development. In areas where local governance and policymaking do not provide tools for the collective imagination of public place, this novel method could be significant for strengthening the community development and place sustainability. The digital workshop shepherded by architectural students significantly cut costs compared to face-to-face workshops. Moreover, the workshop was more inclusive since the communication media is anonymous and time-flexible for receiving inputs from citizens, and efficient in the use of visual tools as facilitators of idea exchange. With social media, the local community could engage in meaningful collaboration by removing traditional institutional barriers and discriminatory power dynamics in social interaction.

Dascalu [58] argues that architecture can play a significant role in social change by building social capital through trust. For this to be possible, architecture has to be understood as an open-ended process, rather than a finished product, that involves a myriad of aspects such as use, function, regulations, policies, and practices, among others. The study results support this theoretical standpoint by demonstrating that the dialectic nature of the design process involving local agents, exerts and municipal officials can provide better place strategies and solutions. A study from MacLaren [59] on a hands-on community design project in Edinburgh, Scotland, showed that methods involving social innovation enhance learning expertise but diminish traditional academic achievements. In other words, the author claims that the soft skills and awareness developed through this type of practice are difficult to evaluate and reward. Through the present research, it was found that a clear methodological conceptual base focused on social extrapreneurial outcomes is very valuable in avoiding possible bias in the evaluation of soft skills that can come out because of different views on socially constructed problems. Moreover, from the students' comments at the end of our course, it seems that they found the process of facilitating change in their community more rewarding than a better grade. On the other hand, Bozovic-Stamenovic [60], while working on two design studios in Serbia and Singapore, pointed out the difficulty in applying a general method for innovation in substantially different local contexts, especially those marred with poverty, marginalization, and lack of power-transfer tools. The study also found that when students are intervening in a familiar context the results are significantly better since they can use pre-existing social relations and intuitive knowledge of socio-spatial patterns. Nevertheless, when the method is applied in foreign contexts, the predesign exploration phase should be extended to first create bonds with key stakeholders and adjust the social media tools to local conditions.

Through the case study, areas for improvement were identified. Even though the digital studio includes a larger sample of the local population than a standard participatory workshop, still the response from the most marginalized group was limited. Since in the presented case most of the students come from relatively well-off families or have acquaintances from inside university groups, the most represented group in the social media interactions was the middle class. In areas with marked social segregation or classism, additional tools are needed to form alliances that include all. Another possible problem comes from the fact that older adults or the urban poor might not have the resources or skills necessary, or indeed the time, to engage in digital media communication. Other 
tools must be developed to enable and incentivize the participation of these groups. A possible solution was proposed by students in developing a type of lottery game, where printed posters could be distributed to local grocery stores where people could vote or express opinions on the design proposals. The municipal official supported this idea offering the contact of local distributors, such as the distributor for Heineken beer, for the delivery and collection of the printed materials and offering a small prize for the winners. This could turn an otherwise unattractive process into a simple game and even add value to the project by promoting awareness and the possibility of power transfer. Furthermore, since the project was focused on social innovation in areas of conflict and marginalization, the ecological aspect of placemaking was not fully enforced. Additional studies are necessary to find ways to balance the anthropocentric approach that always takes president in such urban areas with a more holistic socio-environmental practice.

Finally, the project should not stop abruptly after the termination of the course since it will break the trust of locals who were already invested in building social relations through media transfers. Thus, the process should be open-ended, and subsequent phases should be devised beforehand, to grow the horizontal network. In this case, the following steps involve an assessment of the environmental, social, and economic impact of the project's implementation. The following semester, another group of students will focus on measuring the effects of the possible realization of the project, as well as search for community-based approaches for park management leveraging the formed horizontal network. The study's takeaway message is that the undergraduate architectural studio has the potential for democratization of the public place imagination and could improve the social processes of place production with social media. It remains to be seen how effective the studio can be in managing the process of public place implementation.

\section{Conclusions}

The preliminary results show that the proposed method does foster social innovation in placemaking. The students leveraged their social networks to create partnerships for the greater social impact of the project. In the context of the studio, they acted as extrapreneurs and developed tools and visual communications for an inclusive process of place imagination that is rich and diversified in the concepts and responds better to user needs. Through collaborative platforms, the students developed a horizontal network of stakeholders that included experts, agents from the local government and local community, and several locally-based businesses. The outcomes showed a much better understanding of the value of architecture and better human-centered design proposals than outcomes from groups that did not use the novel method. The research also showed that the students perceived the course significantly improved their social innovation skills and understanding of architecture as a social act. They also felt more engaged with their community and more eager to develop similar projects based on the acquired social innovation skills and digital technology tools. Nevertheless, there is still a gap in their understanding of the link between social innovation in architecture and sustainable development. In the undergraduate architecture classes, the same attention should be paid to the aspect of social innovation as to the technological solutions related to sustainable development to fill this gap.

Funding: This research received no external funding.

Institutional Review Board Statement: Ethical review and approval were waived for this study because the data was obtained from the freely available public domain and open source databases.

Informed Consent Statement: Not applicable. 
Data Availability Statement: The data presented in this study are available on request from the corresponding author.

Acknowledgments: I express my sincere gratitude for the support of the publication of this article to the Associate Dean of Research of the School of Architecture, Art and Design of Tecnologico de Monterrey-Alfredo Henry Hidalgo Rasmussen and the Director of Research Miguel Angel Montoya Bayardo. I thank my research group "Sustainable Territorial Development" of Tecnologico de Monterrey for the constructive feedback and encouragement. I genuinely appreciate the information and support provided by public officials, experts, consultants, and neighborhood leaders, in particular Eng. Areli Figueroa Zuñiga, Eng. Enrique Reyna and Elsa Perez-Paredes.

Conflicts of Interest: The author declares no conflict of interest.

\section{Appendix A}

Table A1. The survey developed by students to find preferences in public space use.

\begin{tabular}{|c|c|c|}
\hline & Survey Question (Translated from the Original SPANISH) & Answer Options \\
\hline \multirow{11}{*}{ Sociodemographic profile } & 1. In which neighborhood do you live? & Open answer, text \\
\hline & 2. What is your sex? & F-female or M-male \\
\hline & 3. What is your age? & Open answer, numerical \\
\hline & 4. What is your highest educational level? & $\begin{array}{l}\text { postgraduate, university graduate, high school } \\
\text { or primary }\end{array}$ \\
\hline & 5. Do you own your house or you rent? & own or rent \\
\hline & 6. Were you born in Atizapan de Zaragoza? & yes or no \\
\hline & 7. Were your parents born in Atizapan de Zaragoza? & yes or no \\
\hline & $\begin{array}{l}\text { 8. How many years do you live in your } \\
\text { current neighborhood? }\end{array}$ & Open answer, numerical \\
\hline & $\begin{array}{l}\text { 9. From } 1 \text { to } 10 \text {, where } 10 \text { is highest, could you indicate } \\
\text { how well do you think you know your neighborhood? }\end{array}$ & 1 to 10 \\
\hline & 10. What is your occupation? & Open answer, text \\
\hline & 11. Where do you spend your free time during workdays? & $\begin{array}{l}\text { a local park, commercial center, gym, regional } \\
\text { park, or other }\end{array}$ \\
\hline \multirow{13}{*}{ Habits in using public space } & 12. Where do you spend your free time during weekends? & $\begin{array}{l}\text { a local park, commercial center, gym, regional } \\
\text { park, or other }\end{array}$ \\
\hline & $\begin{array}{l}\text { 13. Does your daily activities include taking care of } \\
\text { another person? }\end{array}$ & yes or no \\
\hline & 14. If you answered yes to question 12 , who is that person? & $\begin{array}{l}\text { a minor less than } 6 \text { years old, a minor less than } \\
16 \text { years old, an older adult, a person with } \\
\text { incapacity, a sick person, or other }\end{array}$ \\
\hline & $\begin{array}{l}\text { 15. What kind of exercise, recreation or games do } \\
\text { you perform? }\end{array}$ & Open answer, text \\
\hline & 16. Do you perform these activities alone or with someone? & alone or with someone \\
\hline & $\begin{array}{l}\text { 17. If you perform the activities with someone, } \\
\text { who is that person? }\end{array}$ & $\begin{array}{l}\text { children, friend, neighbors, parents, partner, } \\
\text { sports team, pets, or other }\end{array}$ \\
\hline & 18. Where do you perform these activities? & $\begin{array}{l}\text { private sports club, public sports club, at home, } \\
\text { local park, regional park, open-air, or other }\end{array}$ \\
\hline & $\begin{array}{l}\text { 19. What public space near your home do you visit } \\
\text { most often? }\end{array}$ & Open answer, text \\
\hline & 20. How often do you visit that public space? & $\begin{array}{l}\text { every day, once a week, twice a week, three } \\
\text { times per week, on weekends, or other }\end{array}$ \\
\hline & $\begin{array}{l}\text { 21. How much time you need to walk to reach that } \\
\text { public space? }\end{array}$ & $\begin{array}{l}1 \text { to } 5 \mathrm{~min}, 5 \text { to } 10 \mathrm{~min}, 10 \text { to } 20 \mathrm{~min}, 20 \text { to } 30 \\
\text { min, or more than } 30 \mathrm{~min}\end{array}$ \\
\hline & $\begin{array}{l}\text { 22. Which public space close to your house do you } \\
\text { like best? }\end{array}$ & Open answer, text \\
\hline & $\begin{array}{l}\text { 23. Why do you consider that public space more pleasant } \\
\text { than others that exist in your neighborhood? }\end{array}$ & Open answer, text \\
\hline & $\begin{array}{l}\text { 24. Is the public space that you visit most often the same } \\
\text { public space that you like best? }\end{array}$ & yes or no \\
\hline
\end{tabular}


Table A1. Cont.

\begin{tabular}{|c|c|c|}
\hline & Survey Question (Translated from the Original SPANISH) & Answer Options \\
\hline \multirow{10}{*}{ Social relations } & $\begin{array}{l}\text { 25. On a scale from } 1 \text { (low) to } 10 \text { (high), how well do you } \\
\text { know your neighbors? }\end{array}$ & 1 to 10 \\
\hline & $\begin{array}{c}\text { 26. what type of relationship you have with } \\
\text { your neighbors? }\end{array}$ & $\begin{array}{l}\text { we only discuss neighborhood issues, we only } \\
\text { discuss municipal issues, we are friends, we do } \\
\text { not communicate, we have a conflict, or other }\end{array}$ \\
\hline & $\begin{array}{l}\text { 27. Are you aware of citizens' groups or social } \\
\text { organizations in your neighborhood? }\end{array}$ & yes or no \\
\hline & $\begin{array}{l}\text { 28. If you answered yes, are any of the activities of those } \\
\text { citizen groups or social organizations dedicated to } \\
\text { improving public spaces, green areas, sports, recreation, } \\
\text { and exercise areas? }\end{array}$ & yes or no \\
\hline & $\begin{array}{l}\text { 29. Do you participate in a } \\
\text { neighborhood/community group? }\end{array}$ & yes or no \\
\hline & 30. If yes, what is the name of that group? & Open answer, text \\
\hline & 31. What is the main activity of that group? & Open answer, text \\
\hline & $\begin{array}{l}\text { 32. Do you think that the work of social organizations is } \\
\text { important for community life? }\end{array}$ & yes or no \\
\hline & $\begin{array}{l}\text { 33. Thinking about the government's actions aimed at } \\
\text { public spaces, do you consider that these actions } \\
\text { are adequate? }\end{array}$ & yes or no \\
\hline & $\begin{array}{l}\text { 34. Who do you consider responsible for taking care of } \\
\text { public spaces? (You can select more than one) }\end{array}$ & $\begin{array}{c}\text { The municipal government, State government, } \\
\text { Federal Government, social organizations, } \\
\text { neighbors, private companies, or other }\end{array}$ \\
\hline \multirow{15}{*}{$\begin{array}{l}\text { Important features of public } \\
\text { space design }\end{array}$} & $\begin{array}{l}\text { 35. On a scale from } 1 \text { to } 3 \text {, where } 1 \text { is "very important and } 3 \\
\text { is" not very important, "how important is it that the public } \\
\text { space in your neighborhood has infrastructure (games, } \\
\text { gym, benches)? }\end{array}$ & 1,2 or 3 \\
\hline & $\begin{array}{l}\text { 36. How important is it that the public space in your } \\
\text { neighborhood has security (surveillance)? }\end{array}$ & 1,2 or 3 \\
\hline & $\begin{array}{l}\text { 37. How important is it that the public space in your } \\
\text { neighborhood has a fence, fence or is enclosed? }\end{array}$ & 1,2 or 3 \\
\hline & $\begin{array}{l}\text { 38. How important is it that the public space in your } \\
\text { neighborhood has adequate lighting (at night)? }\end{array}$ & 1,2 or 3 \\
\hline & $\begin{array}{l}\text { 39. How important is it that the public space in your } \\
\text { neighborhood is clean? }\end{array}$ & 1,2 or 3 \\
\hline & $\begin{array}{l}\text { 40. How important is it that the public space in your } \\
\text { neighborhood has vegetation that provides shade? }\end{array}$ & 1,2 or 3 \\
\hline & $\begin{array}{l}\text { 41. How important is it that the public space in your } \\
\text { neighborhood has decorative vegetation (ornamental, } \\
\text { gardens, orchards)? }\end{array}$ & 1,2 or 3 \\
\hline & $\begin{array}{l}\text { 42. How important is it that the public space in your } \\
\text { neighborhood has maintenance? }\end{array}$ & 1,2 or 3 \\
\hline & $\begin{array}{l}\text { 43. How important is it that the public space in your } \\
\text { neighborhood is close to your home? }\end{array}$ & 1,2 or 3 \\
\hline & $\begin{array}{l}\text { 44. How important is it that public space in your } \\
\text { neighborhood is accessible to all people (easy access, } \\
\text { ramps, signs for people with blindness, etc.)? }\end{array}$ & 1,2 or 3 \\
\hline & $\begin{array}{l}\text { 45. How important is it that the public space in your } \\
\text { neighborhood has sanitary services and drinking water? }\end{array}$ & 1,2 or 3 \\
\hline & $\begin{array}{l}\text { 46. How important is it that the public space in your } \\
\text { neighborhood has garbage cans? }\end{array}$ & 1,2 or 3 \\
\hline & $\begin{array}{l}\text { 47. How important is it that the public space in your } \\
\text { neighborhood sells food and/or products? }\end{array}$ & 1,2 or 3 \\
\hline & $\begin{array}{l}\text { 48. How important is it that the public space in your } \\
\text { neighborhood rents bicycles, tricycles, skates, } \\
\text { skateboards, etc.? }\end{array}$ & 1,2 or 3 \\
\hline & $\begin{array}{l}\text { 49. How important is it that the public space in your } \\
\text { neighborhood has free WIFI or internet? }\end{array}$ & 1,2 or 3 \\
\hline
\end{tabular}

Source: survey adapted from Pérez-Paredes EA, 2019 [55]. The colors used in the first column indicate four sections of questions-yellow: (1) Sociodemographic profile (questions 1-11); green: (2) Habits in using public space; light blue: (3) Social relations and deep blue: (4) Important features of public space design. 


\section{References}

1. Lefebvre, H. The Production of Space. In Donald Nicholson-Smith, Trans; Basil Blackwell: Oxford, UK, 1991.

2. Bradford, N. Place Matters and Multi-Level Governance: Perspectives on a New Urban Policy Paradigm. 2004. Available online: https:/ / policyoptions.irpp.org/magazines/canadas-cities/place-matters-and-multi-level-governance-perspectiveson-a-new-urban-policy-paradigm/ (accessed on 10 November 2020).

3. Seamon, D. Lived bodies, place, and phenomenology: Implications for human rights and environmental justice. J. Hum. Rights Environ. 2013, 4, 143-166. [CrossRef]

4. Kennedy, A. Scotland's approach to participatory planning: Characterising the charrette. ArchNet-IJAR Int. J. Arch. Res. 2017, 11, 101-122. [CrossRef]

5. Zhang, H.; Mao, Z.; Zhang, W. Design Charrette as Methodology for Post-Disaster Participatory Reconstruction: Observations from a Case Study in Fukushima, Japan. Sustainability 2015, 7, 6593-6609. [CrossRef]

6. Roggema, R.; Martin, J.; Remnant, M.; Alday, G.; Mansfield, P. Design Charrettes in Two Days: Sea Lake and Bendigo. In The Design Charrette; Roggema, R., Ed.; Springer: Berlin/Heidelberg, Germany, 2014. [CrossRef]

7. Al-Kodmany, K. Visualization Tools and Methods for Participatory Planning and Design. J. Urban. Technol. 2001, 8, 1-37. [CrossRef]

8. Salter, J.D.; Campbell, C.; Journeay, M.; Sheppard, S.R. The digital workshop: Exploring the use of interactive and immersive visualisation tools in participatory planning. J. Environ. Manag. 2009, 90, 2090-2101. [CrossRef] [PubMed]

9. McCall, M.K.; Dunn, C.E. Geo-information tools for participatory spatial planning: Fulfilling the criteria for 'good' governance? Geoforum 2012, 43, 81-94. [CrossRef]

10. Dahmann, N.; Wolch, J.; Joassart-Marcelli, P.; Reynolds, K.; Jerrett, M. The active city? Disparities in provision of urban public recreation resources. Health Place 2010, 16, 431-445. [CrossRef] [PubMed]

11. Wolch, J.R.; Byrne, J.; Newell, J.P. Urban green space, public health, and environmental justice: The challenge of making cities 'just green enough'. Landsc. Urban. Plan. 2014, 125, 234-244. [CrossRef]

12. Dirlik, A. Place-Based Imagination: Globalism and the Politics of Place. Review 1999, 22, 151-187, Retrieved 1 December 2020. Available online: http:/ / www.jstor.org/stable/40241454 (accessed on 1 December 2020).

13. Arnstein, S.R. A Ladder of Citizen Participation. J. Am. Inst. Plan. 1969, 35, 216-224. [CrossRef]

14. Tracey, P.; Stott, N. Social innovation: A window on alternative ways of organizing and innovating. Innovation 2017, 19, 51-60. [CrossRef]

15. Mozaffari, A. Towards a Theory of Imagining Places: Collective Imagination and the Process of Inscribing Sites. In Proceedings of the 27th Annual SAHANZ Conference: Imagining, New Castle, Australia, 30 June-2 July 2010; Chapman, M., Ostwald, M., Eds.; Society of Architectural Historians: New Castle, UK, 2010; pp. 296-303.

16. Borer, M.I. From Collective Memory to Collective Imagination: Time, Place, and Urban Redevelopment. Symb. Interact. 2010, 33, 96-114. [CrossRef]

17. Davoudi, S. Resilience: A Bridging Concept or a Dead End? Plan. Theory Pract. 2012, 13, 299-333. [CrossRef]

18. Quick, K.S.; Feldman, M.S. Distinguishing Participation and Inclusion. J. Plan. Educ. Res. 2011, 31, 272-290. [CrossRef]

19. Pierce, J.; Martin, D.G.; Murphy, J.T. Relational place-making: The networked politics of place. Trans. Inst. Br. Geogr. 2010, 36, 54-70. [CrossRef]

20. Nicholls, W. Place, networks, space: Theorizing the geographies of social movements. Trans. Inst. Br. Geogr. 2009, 34, 78-93. [CrossRef]

21. Williams, D.R. Leisure Identities, Globalization, and the Politics of Place. J. Leis. Res. 2002, 34, 351-367. [CrossRef]

22. Elwood, S. Beyond Cooptation or Resistance: Urban Spatial Politics, Community Organizations, and GIS-Based Spatial Narratives. Ann. Assoc. Am. Geogr. 2006, 96, 323-341. [CrossRef]

23. Elwood, S.; Lawson, V.; Nowak, S. Middle-Class Poverty Politics: Making Place, Making People. Ann. Assoc. Am. Geogr. 2014, 105, 123-143. [CrossRef]

24. Martin, D.G. "Place-Framing" as Place-Making: Constituting a Neighborhood for Organizing and Activism. Ann. Assoc. Am. Geogr. 2003, 93, 730-750. [CrossRef]

25. Harvey, D. Justice, Nature and the Geography of Difference, 1st ed.; Blackwell: Oxford, UK, 1996; ISBN 101557866813.

26. Davidson, M. Spoiled Mixture: Where Does State-led 'Positive' Gentrification End? Urban. Stud. 2008, 45, 2385-2405. [CrossRef]

27. Low, S. Spatializing Culture an Engaged Anthropological Approach to Space and Place. PEOPLE, PLACE, SPACE, 2014. Available online: http:/ / opencuny.org/peopleplacespace/files/2014/06/Low-Spatializing-Culture.pdf (accessed on 11 December 2020).

28. McCann, E.J. The cultural politics of local economic development: Meaning-making, place-making, and the urban policy process Geoforum 2002, 33, 385-398. [CrossRef]

29. Terzoglou, N.-I. Architecture as Meaningful Language: Space, Place and Narrativity. Linguistics Lit. Stud. 2018, 6, 120-132. [CrossRef]

30. Smith, N.D. Design Charrette: A Vehicle for Consultation or Collaboration? In Proceedings of the Participatory Innovation Conference 2012, Melbourne, Australia, 12-14 January 2012.

31. Eckenwiler, L. Displacement and solidarity: An ethic of place-making. Bioethics 2018, 32, 562-568. [CrossRef]

32. Wolch, J.; Wilson, J.P.; Fehrenbach, J. Parks and Park Funding in Los Angeles: An Equity-Mapping Analysis. Urban. Geogr. 2005, 26, 4-35. [CrossRef] 
33. Lang, L.; Mell, I. 'I stick to this side of the park': Parks as shared spaces in contemporary Belfast. Environ. Plan E Nat. Space 2020, 3, 503-526. [CrossRef]

34. Barbara, J. Service Learning in Higher Education: Concepts and Practices; Barbara Jacoby and Associates; Jossey-Bass Publishers: San Francisco, CA, USA, 1996; ISBN 0-7879-0291-8.

35. Astin, A.W.; Vogelgesang, L.J.; Ikeda, E.K.; Yee, J.A. How Service Learning Affects Students. Higher Education, 2000,144 Available online: https:/ / digitalcommons.unomaha.edu/slcehighered/144 (accessed on 1 February 2020).

36. Sedlak, C.A.; Doheny, M.O.; Panthofer, N.; Anaya, E. Critical Thinking in Students' Service-Learning Experiences. Coll. Teach. 2003, 51, 99-104. [CrossRef]

37. Engberg, M.E.; Fox, K. Exploring the Relationship between Undergraduate Service-Learning Experiences and Global PerspectiveTaking. J. Stud. Aff. Res. Pract. 2011, 48, 85-105. [CrossRef]

38. Lee, S.J.; Wilder, C.; Yu, C. Exploring students' perceptions of service-learning experiences in an undergraduate web design course. Teach. High. Educ. 2017, 23, 212-226. [CrossRef]

39. Blakey, J.M.; Theriot, S.; Cazzell, M.; Sattler, M. Is Service-Learning Worth it? A Mixed-Methods Study of Faculty's ServiceLearning Experiences. Int. J. Res. Serv.-Learn. Community Engagem. 2015, 3, 251-263. Available online: http://journals.sfu.ca/ iarslce (accessed on 1 February 2020).

40. Reeves, T. The application of "design research" to e-learning. In Proceedings of the First International Conference for eLearning and Distance Learning, Riyadh, Saudi Arabia, 16-18 March 2009; Available online: www.eli.elc.edu.sa/2009/content/ Reeves[research].pdf (accessed on 1 February 2020).

41. Herrington, A.; Herrington, J. Authentic mobile learning in higher education. In Proceedings of the AARE 2007 International Educational Research Conference, Fremantle, Australia, 25-29 November 2007; Available online: http:/ /www.aare.edu.au/07 pap/abs07.htm (accessed on 1 February 2020).

42. Becerik-Gerber, B.; Gerber, D.J.; Ku, K. The pace of technological innovation in architecture, engineering, and construction education: Integrating recent trends into the curricula. J. Inf. Technol. Constr. (ITcon) 2011, 16, 411-432. Available online: http:/ / www.itcon.org/2011/24 (accessed on 1 February 2020).

43. Perez, S. Technology Populism: Risks \& Rewards. Read Write Web, 2008. Available online: http:/ /www.readwriteweb.com/ archives/technology_populism_risks_rewards.php (accessed on 10 November 2020).

44. Hajer, M.; Zonneveld, W. Spatial Planning in the Network Society-Rethinking the Principles of Planning in the Netherlands. Eur. Plan. Stud. 2000, 8, 337-355. [CrossRef]

45. Cochrane, T.; Rhodes, D. iArchi[tech]ture: Developing a mobile social media framework for pedagogical trans-formation. Aust. J. Educ. Technol. 2013, 29, 372-386.

46. Ham, J.J.; Schnabel, M.A. Web 2.0 virtual design studio: Social networking as facilitator of design education. Arch. Sci. Rev. 2011, 54, 108-116. [CrossRef]

47. Dacin, M.T.; Dacin, P.A.; Tracey, P. Social Entrepreneurship: A Critique and Future Directions. Organ. Sci. 2011, 22, 1203-1213. [CrossRef]

48. Kistruck, G.M.; Beamish, P.W. The Interplay of Form, Structure, and Embeddedness in Social Intrapreneurship. Entrep. Theory Pract. 2010, 34, 735-761. [CrossRef]

49. Brown, J.S. New Learning Environments for the 21st Century: Exploring the Edge. Chang. Mag. High. Learn. 2006, 38, 18-24. [CrossRef]

50. Nambisan, S. Platforms for collaboration. Stanf. Soc. Innov. Rev. 2009, 7, 44-49.

51. Newman, M.J. Problem Based Learning: An Introduction and Overview of the Key Features of the Approach. J. Vet. Med. Educ. 2005, 32, 12-20. [CrossRef]

52. Engel, C.E. Not just a method but a way of learning. In The Challenge of Problem-Based Learning; Boud, D., Feletti, G.P., Eds.; Kogan: London, UK, 1991; pp. 22-33.

53. The Boyer Commission on Educating Undergraduates in the Research University. Reinventing Undergraduate Education: A Blueprint for America's Research Universities; State University of New York at Stony Brook: New York, NY, USA, 2001.

54. CPI Report, Atizapan de Zaragoza, 2018. Un Habitat Mexico. Available online: https://www.google.com/search?client=firefoxb-d\&q=CPI+report+Atizapan+de+Zaragoza+2018 (accessed on 11 December 2020).

55. Pérez- Paredes, E.A. De Abajo Hacia Arriba: La Apropiación del Espacio público y su Aporte a la Nueva Agenda Urbana. Un Estudio Comparativo. Postdoctoral Research Project; Consejo Nacional de Ciencia y Tecnología (CONACYT): Ciudad de México, Mexico, 2019. (Manuscript in preparation)

56. Pérez-Paredes, E.A.; Krstikj, A. Spatial Equity in Urban Public Space (UPS) Based on Analysis of Municipal Public Policy Omis sions: A Case Study of Atizapán de Zaragoza, State of México. Societies 2020, 10, 8. [CrossRef]

57. Clavan, B. Embracing the Social Art of Architecture. In DESIGN FOR A NEW AGE: Teaching the Social Art of Architecture; Manuscript_Draft 1: 15 October 2015; Introduction; 2015; pp. 5-7. Available online: https:/ /www.google.com/url?sa=t\&rct=j\& $\mathrm{q}=\&$ esrc $=$ s\&source=web\&cd=\&cad=rja\&uact=8\&ved=2ahUKEwjWtLT7jcbtAhUQPaOKHWQaDX8QFjAAegQIAhAC\&url=

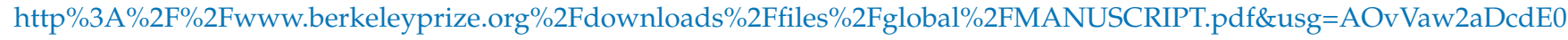
GOlOqhELcJjbk_0 (accessed on 11 December 2020).

58. Dascalu, D. Architecture as Tool for Building Social Capital. Acta Tech. Napoc. Civ. Eng. Arch. 2013, 56, $204-220$. 
59. MacLaren, A. Architecture as a Service Industry. In DESIGN FOR A NEW AGE: Teaching the Social Art of Architecture; ManuscriptDraft 1: 15, October 2015; Chapter 1; 2015; pp. 20-53. Available online: https: / www.google.com/url?sa=t\&rct=j\&q=\&esrc=s\& source=web\&cd=\&cad=rja\&uact=8\&ved=2ahUKEwjWtLT7jcbtAhUQPa0KHWQaDX8QFjAAegQIAhAC\&url=http $\% 3 \mathrm{~A} \% 2 \mathrm{~F} \%$ 2Fwww.berkeleyprize.org\%2Fdownloads\%2Ffiles\%2Fglobal\%2FMANUSCRIPT.pdf\&usg=AOvVaw2aDcdE0GO1OqhELcJjbk_ 0 (accessed on 11 December 2020).

60. Bozovic-Stamenovic, R. Transferring Power in the Design Process. In DESIGN FOR A NEW AGE: Teaching the Social Art of Architecture; Manuscript-Draft 1: 15, October 2015; Chapter 2; 2015; pp. 56-97. Available online: https://www.google. $\mathrm{com} /$ url sa $=$ t\&rct=j\&q=\&esrc=s\&source=web\&cd=\&cad=rja\&uact=8\&ved=2ahUKEwjWtLT7jcbtAhUQPaOKHWQaDX8

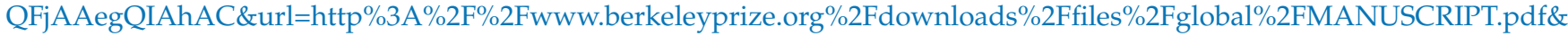
usg=AOvVaw2aDcdE0GOlOqhELcjjbk_0 (accessed on 11 December 2020). 